\title{
Possibilities for improving the conservation of grass by drying
}

\author{
By J. M. Wilkinson and R. J. Wilkins, The Grassland Research Institute, \\ Hurley, Maidenhead, Berks SL6 ${ }_{5} L R$
}

The conservation of grasses and forage crops by drying involves either the drying of crops in the field, to produce hay, or dehydration at high temperatures using fossil fuels to produce dried forage. In this paper, current practice with regard to the production of hay and dried forage is first described in terms of the amounts that are produced and their average contents of metabolizable energy (ME) and crude protein (CP). The potential for ruminant animal production from hay and dried forage is considered, and some ways of improving the efficiency of these conservation methods are indicated.

\section{Hay and dried forage-current practice}

Despite recent increases in the quantity of crop dry matter (DM) conserved in the form of silage (Wilkinson, I $980 a$ ), hay remains the dominant method of forage conservation in the UK and in the European Economic Community (Table I). Dried forage comprises a small proportion of the total DM conserved, and its production has shown a marked decrease (30\%) in the UK in 1979 compared to 1978 (British Association of Green Crop Driers, BAGCD, unpublished results). The main reason for the decrease is economic. The relatively large increases in the cost of fossil fuel and in the cost of replacing depreciated dehydration equipment have combined to make the economic climate for the drying of crops in large, specialist, units relatively unfavourable.

Production of hay has remained fairly static in the UK during the last two decades (Wilkinson, 1980a). Despite the large increase in silage making only a small proportion of farmers have completely abandoned haymaking (Jones, 1979).

Table I. Production of dried forage, hay and silage in the UK and European Economic Community (EEC), 1978/79

\begin{tabular}{llr} 
& \multicolumn{1}{c}{$\begin{array}{c}\text { Production } \\
\text { (million t DM) }\end{array}$} \\
Method of conservation $_{\text {UK }}$ & EEC \\
Hayt forage & 0.1 & $\mathrm{I} \cdot 5$ \\
Silaget & 6.9 & 54.8 \\
& 5.5 & 47.6
\end{tabular}

-From British Association of Green Crop Driers (unpublished data).

†From Wilkinson (1980b).

$\infty 029-6651 / 80 / 3933-4303$ Sor .00 (C) 1980 The Nutrition Society 
Table 2. Average contents of metabolizable energy and crude protein in dried forage, hay and silage made in England and Wales

$\begin{array}{lcc}\text { Method of conservation } & \begin{array}{c}\text { Metabolizable energy } \\ \text { (MJ/kg DM) }\end{array} & \begin{array}{c}\text { Crude protein } \\ \text { (g/kg DM) }\end{array} \\ \text { Dried forage } & 9 \cdot 4 & \text { 180 } \\ \text { Hay } † & 8 \cdot 9 & 96 \\ \text { Silage } † & \text { IO } 1 & \text { I } 44\end{array}$

-From BAGCD (unpublished results for 1972/73), MAFF (1975), Knight \& Barber (1980).

†From Barber \& Altman (1976), MAFF (1979).

In the UK, hay is usually made from field-dried crops cut once in reproductive growth in the period from late-May to July, often in fields previously grazed in the spring. The use of barn-drying or chemical preservatives in haymaking is relatively low and probably accounts for about $5 \%$ of the total hay DM. The composition of samples of hay analysed in England and Wales indicates that this method of conservation is associated with the production of material of relatively low nutritive value (Table 2).

By contrast, dried forage is made from crops harvested relatively frequently. In the case of grasses, the interval between harvests is commonly 5 weeks and grass for dehydration receives high levels of fertilizer nitrogen. Lucerne is an attractive proposition for dehydration because the crop does not require fertilizer nitrogen and can give reasonably high yields when grown under conditions of relatively low rainfall and when harvested solely for conservation (Spedding \& Diekmahns, 1972). Lucerne probably comprises $50 \%$ of the total dried forage produced in the UK.

The production of silage is usually integrated with the grazing of pasture to a much greater extent than with the previous methods of conservation. The ME content of the material (Table 2) reflects a relatively shorter period of growth in spring prior to conservation than with haymaking. Earlier harvest is made possible because ensilage is less weather-dependent than is haymaking. The use of highoutput machinery in silage making has meant that this method of conservation has developed to a greater extent on farms which have a relatively high requirement for conserved forage (such as dairy farms) and on farms which have sufficient labour

Table 3. Effect of size and type of farm on the proportion of total grass DM conserved as hay in $1974(\%) *$

\begin{tabular}{|c|c|c|c|c|}
\hline \multirow[b]{2}{*}{ Type of farm } & \multicolumn{4}{|c|}{ Size of farm (SMD) } \\
\hline & $275-599$ & $600-1199$ & $1200-2399$ & $>2400$ \\
\hline $\begin{array}{l}\text { Dairy } \\
\text { Mixed }\end{array}$ & $\begin{array}{l}83 \\
88\end{array}$ & $\begin{array}{l}62 \\
86\end{array}$ & $\begin{array}{l}42 \\
69\end{array}$ & $\begin{array}{l}26 \\
44\end{array}$ \\
\hline
\end{tabular}

SMD, Standard man days.

-From MAFF (1976). 
available to organize the work in teams of three or more persons (MAFF, 1978). Thus, the proportion of the total DM conserved as hay is lower on dairy farms than on less-specialized mixed livestock-arable farms, and markedly lower on large units than on small farms (Table 3 ).

Surprisingly, there appear to be no marked regional differences in England and Wales in the proportion of total DM conserved as hay, which averaged $66 \%$ in 1974. However, in that year the proportion was lower in Scotland $(57 \%)$ and Northern Ireland (42\%) than elsewhere in the UK (MAFF, 1976).

There is little information on the contribution made on farms by conserved forages in general, and hay in particular, to the nutrition of ruminant livestock. Estimates suggest that about $80 \%$ of the total ME requirement of the ruminant population of the UK is met from grass and forage crops (NEDO, r977); for dairy cattle the contribution appears to be between 54 and $66 \%$ of total requirement (MMB, 1977). Thomas (1980) reviewed MAFF survey data, and concluded that forages (mainly conserved grass) supplied only 43 to $51 \%$ of the winter $\mathrm{ME}$ requirement of dairy cattle.

Recent results from a three-year survey of farms with at least $50 \%$ of the total land devoted to permanent pasture (Forbes et al. 1980) indicated that on dairy farms which made mainly hay ( $75 \%$ or more of the total DM conserved) the contribution of grass to the annual ME requirement was slightly less than that on dairy farms which made silage, implying a somewhat greater contribution by silage than hay to the winter energy supply of the cattle (Table 4).

\section{Potential animal production from hay and dried forage}

The low contribution of hay and dried forage to the nutrition of animals reflects not only the relatively low nutritive value of the materials, particularly hay (Table 2), but also a traditional view that it is necessary to feed cereal grain or compounded feeds (concentrates) in order to produce weight gain in beef cattle or milk from dairy cows. Increased animal performance is achieved by inclusion of higher levels of concentrate in the diet.

Table 4. Contribution of grass to annual ME requirement on dairy farms with permanent pasture which made either hay or silage*

$\begin{array}{lcc} & \overbrace{\text { Hay }}^{\text {Method of forage conservation }} & \begin{array}{c}\text { Silage } \\ \text { No. of farms }\end{array} \\ \begin{array}{l}\text { Total annual ME requirement } \\ \text { (GJ/cow equivalent) }\end{array} & 135 & 119 \\ \begin{array}{l}\text { ME from grass } \\ \text { (\% total annual requirement) }\end{array} & 55 & 43 \\ \begin{array}{c}\text { Stocking rate } \\ \text { (cow equivalent/ha) }\end{array} & \mathrm{I} \cdot 8 & 58 \\ \text { Fertilizer } N(\mathrm{~kg} / \mathrm{ha}) & 133 & 177\end{array}$

- From Hopkins (unpublished results, GRI/ADAS Permanent Pasture Group). 
Recent studies at Drayton Experimental Farm have highlighted the value of hay made from relatively young grass as a feed for finishing beef cattle. Hay, made with barn-drying in mid-June from regrowth following a grazing by sheep the previous April, contained II MJ $/ \mathrm{kg}$ DM of ME and $140 \mathrm{~g} / \mathrm{kg}$ DM of crude protein. When given as the sole feed to Friesian steer cattle, initially 14 months of age, live-weight gains averaged $\mathrm{r} .0 \mathrm{~kg} / \mathrm{d}$ over three consecutive winter periods. Further, the addition of $\mathrm{I} \mathrm{kg} / \mathrm{d}$ of supplementary barley had very little effect on performance; gains were increased by an average of only $47 \mathrm{~g} / \mathrm{d}$ (R. Bee, personal communication). Dried forage has supported similar rates of live-weight gain. Tayler \& Lonsdale (1970) reported a linear increase in live-weight gain with increasing digestibility of long dried grass from $0.6 \mathrm{~kg} / \mathrm{d}$ at $63 \%$ digestibility of organic matter (OMD) to $\mathrm{I} \cdot 0 \mathrm{~kg} / \mathrm{d}$ at $80 \% \mathrm{OMD}$. The response to inclusion of $50 \%$ of concentrate in the total diet DM was inversely related to the OMD of the dried forage.

Dried grass of high digestibility sustained an average milk yield of $23.7 \mathrm{~kg} / \mathrm{d}$ between weeks 3 and 17 of lactation when offered to cows as the sole feed in the long form (Strickland, I974), but dehydrated forages are usually processed into cobs or pellets to facilitate transportation and storage. In addition, the comminution of particles during processing affects nutritive value, as reviewed by Osbourn et al. (1976). In particular, intake potential of rations including dried forage is increased. Thus, the role of processed dried forages in the diet of highproducing ruminants is generally considered to be an alternative to concentrates (e.g. Castle \& Watson, 1975).

The extent to which concentrates can be replaced by dried forage depends to a large extent on the digestibility and content of crude protein in the material, and also on the feeding system practised. Tayler \& Aston (1976a) found that similar levels of milk yield were achieved when grass silage, offered ad lib. was supplemented with the same quantity of either dried forage or a barley-based concentrate. Intake of silage was greater when dried forage was offered than in the case of the barley concentrate. This and other trials (e.g. Tayler \& Aston, 1976b) indicated that lactation yields approaching 60001 should be achievable from autumn-calving dairy cows given diets consisting entirely of conserved forage during the winter.

The low degradability in the rumen of the protein in grass dehydrated at high temperatures is likely to be particularly important in the achievement of high milk yields. The effects of dehydration on protein digestion and metabolism were reviewed by Goering \& Waldo (1979) and at Hurley, Beever \& Thomson (1977) reported that the percentage of feed protein degraded in the rumen was only $29 \%$ for dehydrated chopped grass compared with $85 \%$ for ensiled grass.

\section{Possibilities for improving conservation by drying \\ Production of dried forage}

Despite low DM losses during the production of dried forage, estimated by Christensen (1967) as $2 \%$, and high potential rates of animal production through 
Table 5. Costs in 1978 for the production of dried forage in monetary and energy terms*

(Values in parentheses indicate the percentage each item contributes to the total)

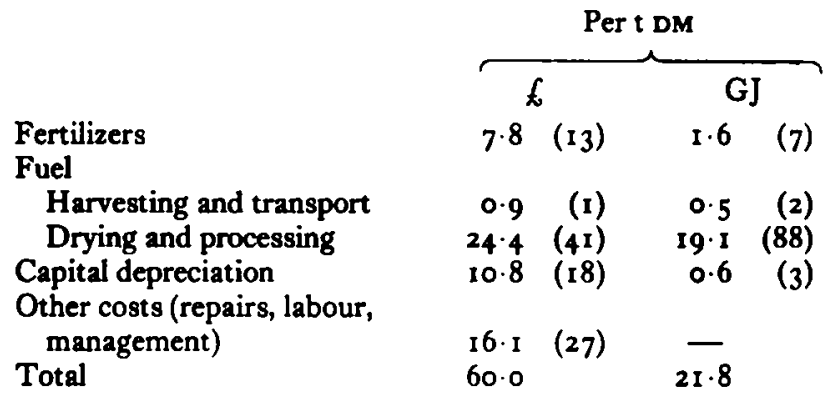

Enterprise producing $10000 \mathrm{t} \mathrm{DM} /$ year, half ryegrass and half lucerne. Results from White (1980) and Heath et al. (1979) with additional unpublished results.

feeding dried forage, the adoption of this method of conservation has, as already noted, been slight. The major limiting factor is the relatively high cost of conservation, particularly in fuel oil.

Table 5 gives information relating to 1978 for the cost of conservation by dehydration and for the inputs of support energy. The largest element of both monetary and energy cost is fuel which amounted to $4 \mathrm{I}$ and $88 \%$ of the totals respectively. The energy use of $21.8 \mathrm{GJ} / \mathrm{t} \mathrm{DM}$ is much higher than values of 2.9 and $4.3 \mathrm{GJ} / \mathrm{t}$ DM given by White (1980) for field-cured hay and silage respectively. The monetary cost of $f_{6} 60 / \mathrm{t}$ DM (or $f_{6}^{6 / G J}$ ME) is much higher than costs in the same year of $63.5 / \mathrm{GJ}$ ME for grass silage production (Walsh, 1979) and 64.2/GJ ME for barley grain production (derived from Sheldrick \& Wilkinson, 1980). The recent increases in fuel prices would have increased costs of production more for dried forage than for silage or barley.

The capital requirement for dried forage production is high with the results in Table 5 based on $\$ 765000$ for equipment to harvest, dry and pellet $10000 \mathrm{t} \mathrm{DM}$ per year. This gave a depreciation charge amounting to $18 \%$ of the monetary cost, despite the equipment being used for about $2000 \mathrm{~h} /$ year. For smaller-scale enterprises there is a disproportionate increase in capital cost per tonne of dried forage produced and capital costs would increase further if the plant were used for fewer hours/years, such as would occur if dehydration were used simply to replace conventional hay or silage making.

There do not appear to be any outstanding opportunities for reducing the capital cost of the equipment used for forage dehydration other than through increasing output achieved from the plant per year by increasing the drying season or by increasing output/h. Any steps to increase the efficiency of fuel use are likely to result in increases in hourly output of dried forage, because throughput is normally limited by the quantity of fuel used/h. Thus, both capital costs (per tonne output) and energy costs would be reduced by increases in the efficiency of fuel use. 
Field wilting. Wilting in the field to increase DM content from 18 to $35 \%$ reduces the energy required for drying from 17.2 to $6.8 \mathrm{GJ} / \mathrm{t} \mathrm{DM}$ (White, I980), halving the total energy input in dried forage production. Periods of field wilting up to $24 \mathrm{~h}$ are now being successfully operated in drying plants in Britain as discussed by Haines (1979). With wilted materials there are increases in the risks of damage to the crop during dehydration and of damage to drying equipment through ignition, but improved dryer control systems such as those described by Taylor (1979) and Jouin (1979) should facilitate safe dehydration of crops with DM content of up to $35 \%$. The introduction of field wilting will lead to some losses of DM in the field and little change in DM content will occur in damp weather conditions.

Low-energy drying systems. Several systems for increasing the thermal efficiency of drying plant are now commercially available. The simplest involving recycling moist exhaust gases to the drier and improved combustion systems (Van den Broek, I979) can be used with both wilted and unwilted crops. The efficiency of use of fuel for drying and plant throughput rates were both reported by Van den Broek (1979) to be increased by $10 \%$.

Another approach involves ( $I$ ) heat treatment of wet crops to coagulate protein, (2) the extrusion of 'deproteinized' juice using a screw press, (3) the evaporation at low pressure of the deproteinized juice to about 50\% DM in a multiple-effect evaporator using exhaust gas from the main drying drum and (4) return of evaporated deproteinized juice to the original crop for final drying. The high thermal efficiency of the evaporator and the use of exhaust gas results in a reduction in the fuel used in dehydration which approaches 50\% (Kunz, 1979; Mogensen \& Israelsen, 1979). These systems can, however, only be used with unwilted crops and have high extra capital costs.

Heath et al. (1979) examined the economics of setting up new plant in Britain for drying and producing ro $000 \mathrm{t}$ forage $\mathrm{DM} / \mathrm{year}$ and found that the capital requirement was $30 \%$ higher for the low-energy system; high capital costs resulted in only a small over-all advantage for the low-energy system. The possibilities of adapting forage drying to produce, in addition, leaf-protein concentrate were also discussed by Heath et al. (1979).

Straw as a fuel. Recent advances in the use of straw as a fuel are described by Staniforth (1979) and the effect on energy budgets of the use of straw for crop drying were considered by Wilkinson ( $1980 \mathrm{c}$ ). He calculated that on an annual basis in a system involving the drying of unwilted crops, the straw from 3 ha of cereal crops would provide sufficient energy for drying forage from I ha. Since forage drying is practised mainly in the east of England where there are large areas of cereal crops, this approach could be attractive in the future. However, hightemperature dryers have not yet been developed for use with straw as a fuel and, because straw is of low-energy density, they would probably be more expensive than existing equipment. Also, it is possible that more effective ways of using the energy in straw may be developed.

Table 6 summarizes the impact of these possible developments on the need for fuel oil energy in forage drying. The total input of energy for the production of 
Table 6. Possibilities for reducing fuel oil energy inputs in forage drying $(G \mathcal{F} / t D M)^{\bullet}$

Conventional drying equipment

Exhaust gas recycling and improved furnace (based on Van den Broek, 1979) Low-energy system (based on Mogensen \& Israelsen, 1979)

Use of straw as a fuel

$\begin{array}{cc}\begin{array}{c}\text { Unwilted } \\ \text { forage } \\ 17.2\end{array} & \begin{array}{c}\text { Wilted } \\ \text { forage }\end{array} \\ 15.5 & 6.8 \\ 10.1 & 6.1 \\ 0 & -\end{array}$

-Fuel for drying only; no allowance for harvesting, grinding and pelleting.

dried forage through the use of wilted forage and exhaust gas recycling could become $10.7 \mathrm{GJ} / \mathrm{t} \mathrm{DM}$, but this is still markedly above the energy input in hay or silage production.

\section{Haymaking}

The major problem associated with haymaking is the dependence of the process on good weather for drying the swath in the field. Not only is suitable weather necessary at the outset, but as drying proceeds it becomes increasingly important that good drying conditions are maintained. This is because the rate at which the

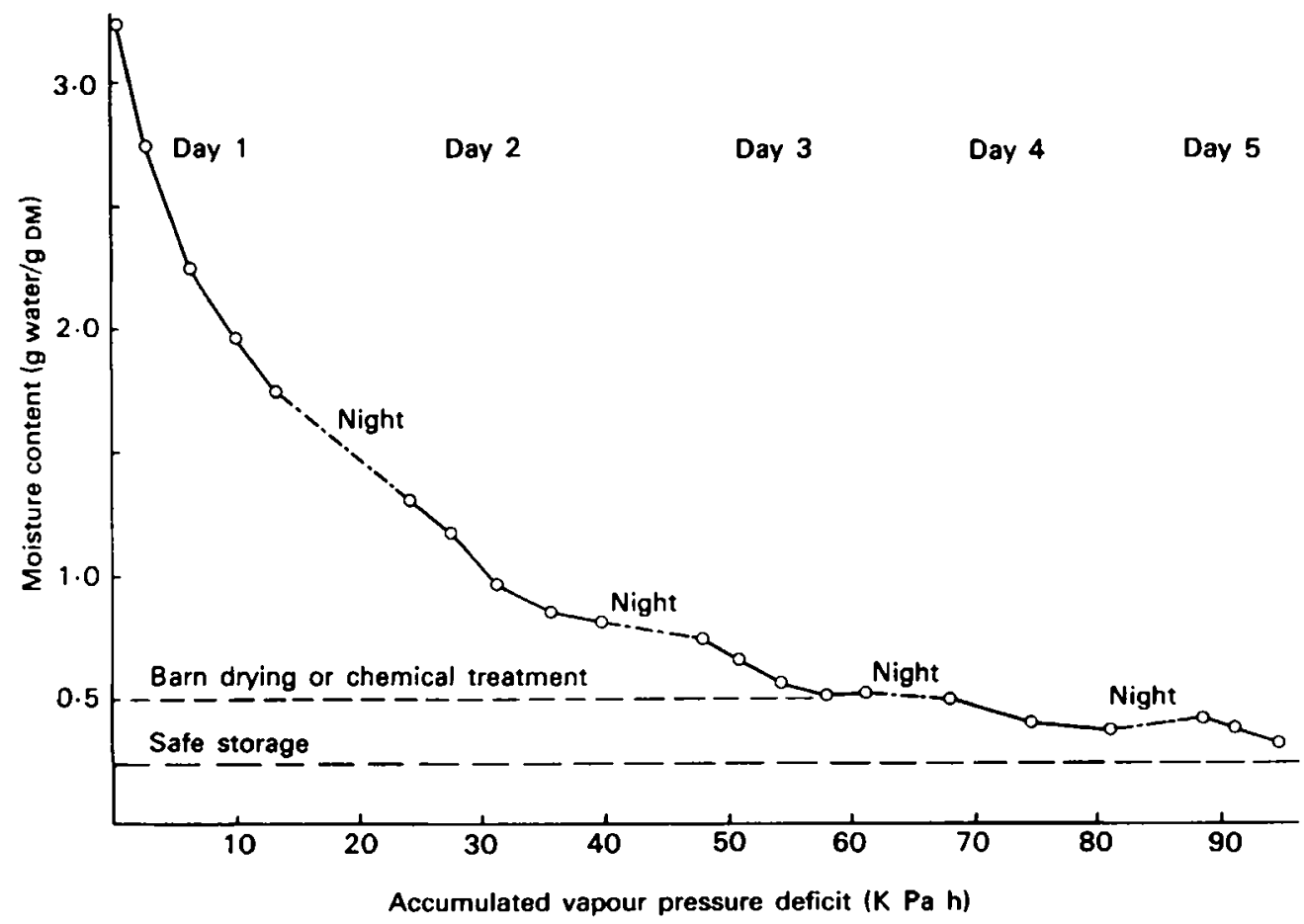

Fig. 1. Rate of drying in the field of a swath of perennial ryegrass (reproductive crop; L. Jones, unpublished results). 
crop dries decreases as drying proceeds (Spatz et al. 1970; Hill, 1976). Typical results for a swath of perennial ryegrass drying under field conditions without rain in late May are shown in Fig. I.

Water content decreased rapidly during the first day and night, but the crop did not reach a moisture content suitable for safe storage as field-dried hay until towards the end of the fifth day in the field. In contrast, the crop had reached a moisture content suitable for harvest with a preservative or subsequent barndrying after only three days of field-drying.

Losses of DM are increased and nutritive value is decreased to a greater extent the longer the drying period. This point is well-illustrated by the results shown in Fig. 2 from experiments conducted in the Federal Republic of Germany. Even in good weather, average loss of DM during drying in the field more than doubled as DM content was increased from 60 to $80 \%$.

Klinner (1976) found that losses between cutting and baling in nine experiments with grasses and four with lucerne averaged $19.1 \%$ (range 8.1 to 28.7 ) and $38.9 \%$ (range 27.4 to 54.5 ) respectively. In these trials, 'traditional' methods of haymaking were employed (i.e. reciprocating knife mower, followed by swath tedding or turning). The high value for loss with lucerne probably reflects the

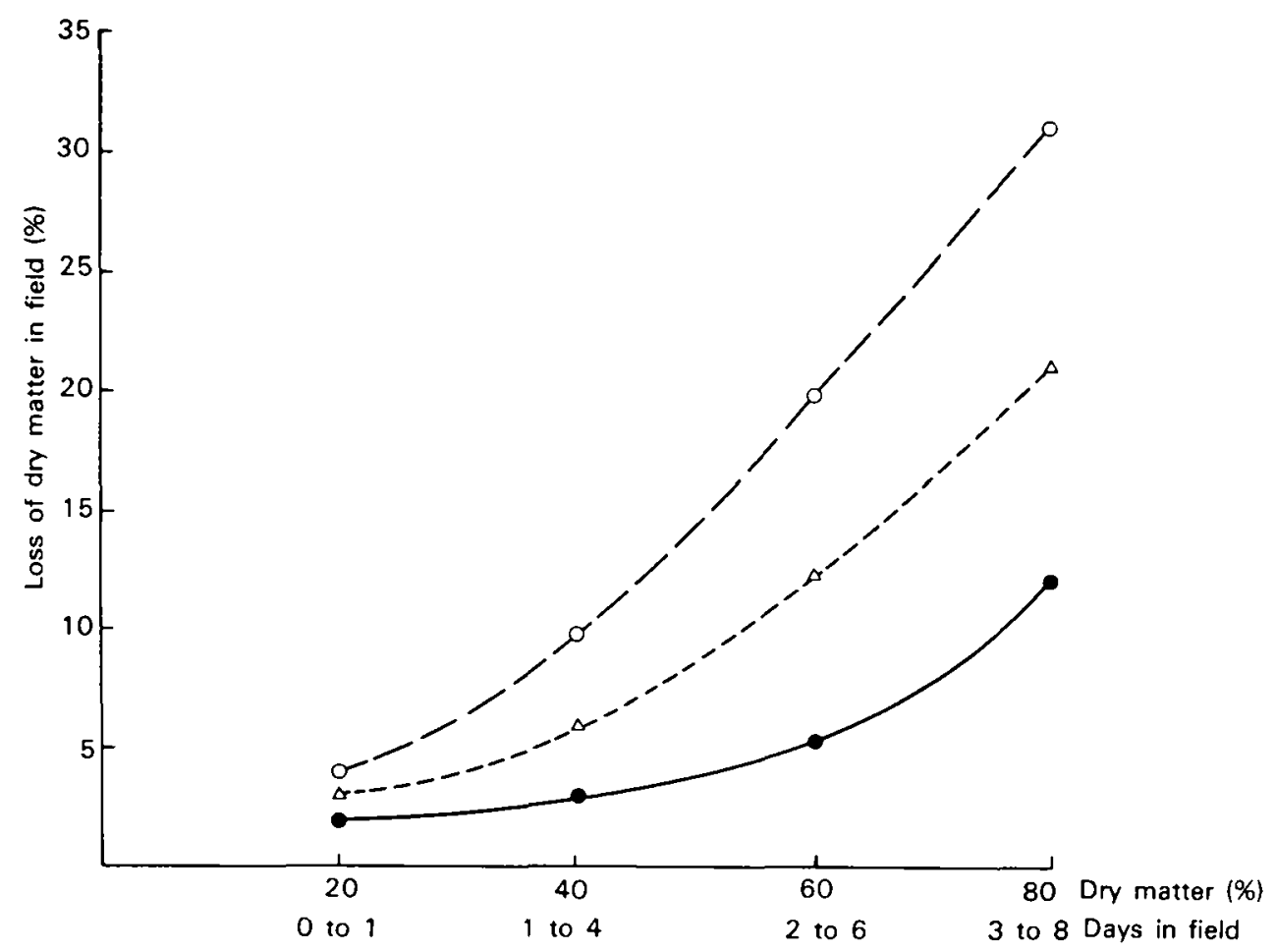

Fig. 2. Losses of DM during drying in the field in various weather conditions. $\mathrm{O}--\mathrm{O}$, poor; $\triangle---\Delta$, moderate;

Q, good. From Zimmer (1977). 
Table 7. Effect of haymaking on digestibility of organic matter and content of crude protein*

(Mean values of nine comparisons)

$\begin{array}{lcc} & \begin{array}{c}\text { Crude protein } \\ \text { g/kg DM }\end{array} & \begin{array}{c}\text { Digestibility of OM } \\ \text { in vivo(\%) }\end{array} \\ \text { Grass at cutting } & 107 & 72 \cdot 5 \\ \text { Barn-dried hay } & 107 & 69 \cdot 1 \\ \text { Field-cured hay } & 90 & 64.4\end{array}$

-From Shepperson (1960).

extent to which the legume is prone to leaf loss following mechanical treatment in the field.

Losses of DM are reflected in decreased energy value and, to a lesser extent, decreased contents of crude protein in the DM. Shepperson (1960) found that the mean reduction, in nine comparisons, in OMD in vivo of barn-dried and field-dried hays compared with fresh grass were 3.4 and $8.1 \%$ respectively (Table 7 ). The decrease appears to be greater for young leafy crops of high OMD at cutting than for more mature crops. There is also a marked effect of rain on the decline in energy value, since the difference in the effect of haymaking on digestibility was very small between barn-dried hays and crops dried in the field without rain (Fig. 3).

Compared to the fresh crop, voluntary intake of digestible organic matter (DOM) was decreased by an average of 21,23 and $34 \%$ for barn-dried hay, fielddried hay made without rain and field-dried hay made with rain, respectively (Demarquilly \& Jarrige, 1970).

Despite the losses which can occur during haymaking, the fact that crops destined for hay are normally allowed to mature before being cut means that digestibility at cutting is commonly quite low. Thus, cutting crops for hay at an earlier stage of growth, and making hay from less-mature regrowths are obvious possibilities for improving nutritive value.

In a recent three-year study at the Grassland Research Institute, Tetlow (1980) found that the production of hay of high quality (68\% DOM in DM and $170 \mathrm{~g} \mathrm{CP} / \mathrm{kg} \mathrm{DM}$ ) was possible by employing a multiple cutting strategy in which ryegrass was cut for hay three times during the season at seven-week intervals. But compared to a traditional system, in which grass was defoliated in spring then cut once for hay in late June, field losses of DM during haymaking were almost twice as high for the multi-cut than for the traditional system (average 26 and $14 \%$ for the three-cut and one-cut systems, respectively).

Acceleration of water loss during drying should lead to improved nutritive value, particularly with field-dried hays. Klinner \& Shepperson (1975) and Klinner (1976) discussed the effects of different cutting and post-cutting treatments on rate of drying and on the improvement in yield of baled hay over that of a control 
Artificially dried grasses ( $n$ 17)

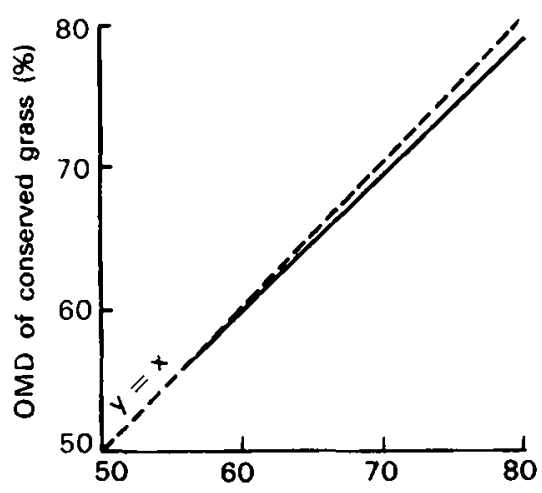

Barn-dried hays (n 31)

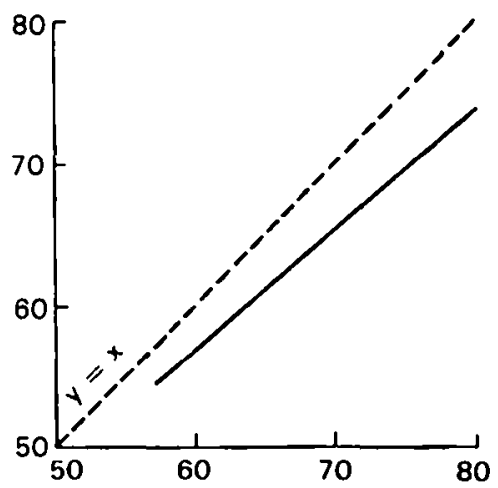

80

OMD of fresh grass (\%)

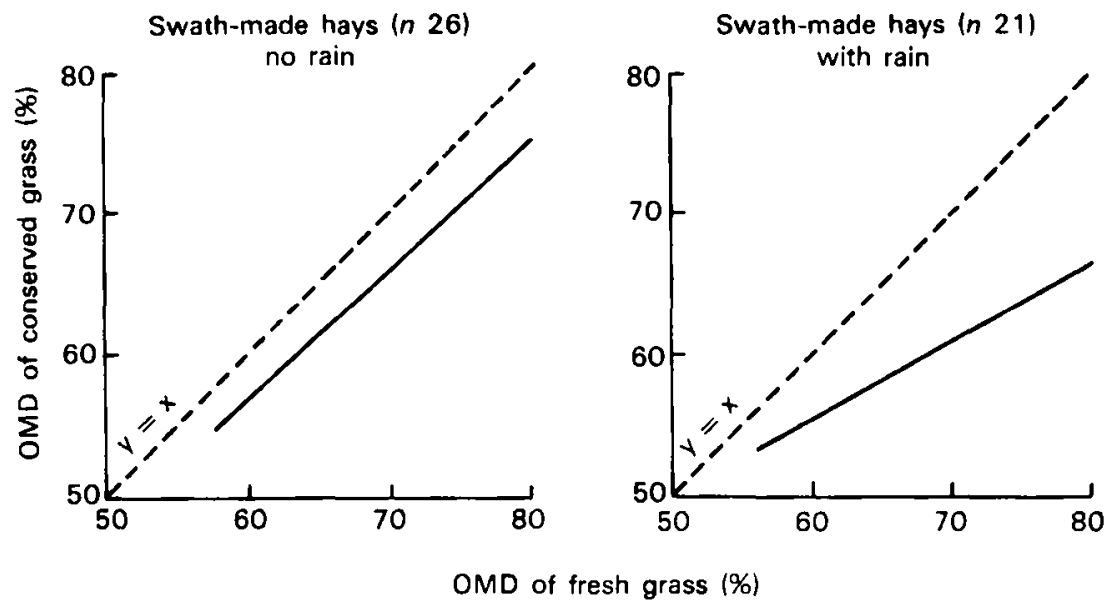

Fig. 3. Effect of initial crop digestibility of organic matter (OMD) and method of drying on OMD of conserved product.

treatment (reciprocating mower with subsequent tedding or turning). Use of a flail mower can be beneficial in terms of accelerating water loss from the cut crop in good weather, but can lead to greater losses due to leaching if rain occurs. The development of mower-conditioners, which scuff and abrade the plant cuticle without shredding and fragmenting the tissues, has resulted in higher yields of baled hay DM in UK experiments than either the control treatment (by 10 to $15 \%$ ), or treatment involving cutting with a flail mower (by 7 to $12 \%$ ) (Klinner, 1976).

Certain grass species appear to show less resistance to water loss after cutting than others. One such species is tall fescue, which, under controlled environmental conditions, took only $14.6 \mathrm{~h}$ to reach $50 \%$ moisture content (DM basis) compared 
to $69.7 \mathrm{~h}$ for perennial ryegrass harvested at a similar stage of growth (Jones \& Prickett, 1979). Field-scale trials are, however, needed to confirm this promising initial result.

The decrease in the rate at which crops lose water as drying proceeds has already been noted (Fig. I). An attractive approach to improve hay conservation is to remove the crop from the field before it has reached the low moisture content necessary for safe storage. In this way, the time the crop is at risk from adverse weather is reduced, as is the number of mechanical field treatments between cutting and baling. The methods adopted to facilitate harvest of moist hay comprise barn-drying or addition of a preservative such as propionic acid or ammonium bispropanoate at the time of baling (Electricity Council, 1975; Klinner \& Shepperson, 1975; Klinner, 1976; Holden \& Sneath, 1980; Lacey et al. 1980). Barn-drying is reflected in reduced loss of DM in the field (Culpin, 1962), improved digestibility (Table 5, Fig. 3, MAFF, 1977) and increased voluntary intake (Demarquilly \& Jarrige, r 970 ) compared to field-drying of hay.

It is appropriate to note, however, that improvements following the use of barndrying may be small when the comparison is made with field-dried hay made in the absence of rain (Shepperson, 1960; McCarrick, 1966; Demarquilly \& Jarrige, 1970). Thus, the adoption of tactical methods such as addition of preservatives, which can be used or not depending on actual and forecasted weather conditions, and which do not require large investment of capital, are likely to prove more attractive than barn-drying. Klinner \& Shepperson (1975) concluded that the relative unpopularity of barn-drying reflected difficulties of matching the capacity of the dryer to the uneven pattern of hay production, and of fitting the drying system to the handling methods used on farms. In a recent survey, Jones (1979) found that $70 \%$ of farmers who had decided not to adopt barn-drying had done so because they regarded a dryer as either too expensive or unnecessary.

The use of preservatives in haymaking is at present in its infancy. Research attention has been focused on application technology because of problems of uneven application and large losses of chemical in the field (Klinner, 1976). Also preservatives based on propionic acid can be metabolized by spoilage organisms if their growth occurs initially in untreated pockets (Lacey et al. 1980). It is hoped that further developments in spraying technique will enhance the effectiveness of preservatives. Nevertheless, trials in which hay has been effectively preserved with addition of ammonium bispropanoate have shown the nutritive value of the stored products to be similar to that of barn-dried material (Strickland, 1979; Tas, 1979).

The feasibility of improving the nutritive value of hay by physical treatment has recently been investigated. The results in Table 8 are for a crop of tall fescue, conserved either as hay ( $4 \mathrm{~d}$ in the field, good weather) or as high-temperature dried material. Although physical treatment was reflected in marked depressions in digestibility in vivo with both hay and dried forage, intake of DM and ME, and weight gain were improved following physical treatment. It is noteworthy that in this experiment the differences in nutritive value between hay and dried forage were very small, reflecting the good weather experienced during haymaking. In 
Table 8. Effect of physical treatment of hay and artificially dried forage on nutritive value to sheep*

\begin{tabular}{|c|c|c|c|c|}
\hline & \multicolumn{2}{|c|}{ Hay } & \multicolumn{2}{|c|}{ Dried forage } \\
\hline & Chopped & $\begin{array}{l}\text { Milled + } \\
\text { pelleted }\end{array}$ & Chopped & $\begin{array}{l}\text { Milled + } \\
\text { pelleted }\end{array}$ \\
\hline Voluntary intake & & & & \\
\hline$D M(k g / d)$ & I. 04 & $\mathbf{I} \cdot \mathbf{8 r}$ & $1 \cdot 03$ & I.44 \\
\hline ME (MJ/d) & $10 \cdot 6$ & $12 \cdot 6$ & 10.9 & I3.9 \\
\hline Digestible OM in DM (\%) & 65.4 & $45 \cdot 6$ & $67 \cdot 5$ & $62 \cdot 3$ \\
\hline Live-weight gain (g/d) & 140 & 206 & 148 & 203 \\
\hline
\end{tabular}

-From Tetlow et al. (1979).

another trial (Thomas et al. 1980) young cattle given either chopped or ground and pelleted hay as supplements to grass silage ad lib. gave similar levels of live-weight gain when the hay comprised $50 \%$ of the total diet DM. But gains were lower than when dried forage, made from the same crop, was given at a similar level of supplementation $(0.69 v .0 .92 \mathrm{~kg} / \mathrm{d}$ for hay and dried forage, respectively). In this trial the hay was baled $5 \mathrm{~d}$ after cutting and received rain during the drying period.

An exciting possibility is that low-quality hays may be upgraded by addition of alkali, in a similar manner to straws (see review by Jackson, 1977). Mwakatundu \& Owen (1974) demonstrated in vitro that the response in OMD to addition of sodium hydroxide $(\mathrm{NaOH})$ was inversely related to the OMD of the crop prior to treatment. Treatment with alkali thus provides an opportunity for combining the high grass yield that can be obtained from grass cut infrequently with improved digestibility. In an experiment at the Grassland Research Institute, a crop of tall fescue was harvested at a mature stage of growth. Part of the crop was conserved as field-dried hay ( $4 \mathrm{~d}$ in the field) and part was harvested at $70 \%$ DM by forage harvester the day before baling and ensiled after addition of $\mathrm{NaOH}$ at $70 \mathrm{~kg} / \mathrm{t} \mathrm{crop}$ DM. Addition of $\mathrm{NaOH}$ resulted in a marked increase in intake of $\mathrm{DM}$, and in the content of DOM in the DM. Sheep given the untreated hay lost weight whilst those given the treated material gained in weight (Table 9).

Table 9. Effect of treatment of low-quality hay with sodium hydroxide on nutritive value to sheep"

$\begin{array}{lcc} & \text { Untreated } & \begin{array}{c}\text { Treated with } \\ \mathrm{NaOH}\end{array} \\ \text { Voluntary intake } & & \\ \text { DM kg/d } & 0.55 & 0.92 \\ \text { ME MJ/d } & 3.89 & 7.61 \\ \text { Digestible OM in DM (\%) } & 47 \cdot 2 & 55 \cdot 5 \\ \text { Live-weight change g/d } & -25 & +43\end{array}$

-From Tetlow et al. (1979). 
A further development of the technology for improving the nutritive value of hays by chemical treatment would be to use ammonia instead of sodium hydroxide. Ammonia has been used with some success as a preservative for moist hay, at levels of addition of 5 to $40 \mathrm{~kg} / \mathrm{t}$ hay fresh weight (Knapp et al. 1974; Kuntzel et al. 1980). Recent trials in Denmark with baled moist hay in plastic covered stacks have demonstrated that at 30 to $35 \mathrm{~kg} \mathrm{NH}_{3} / \mathrm{t}$ hay fresh weight the material is stable in air when the stack is opened, and that OMD is improved. In one experiment with sheep, addition of ammonia was reflected in an increase in OMD from $69.7 \%$ for the crop at baling to $74.1 \%$. Barn-dried hay, removed from the field at the same time, had an OMD of $69.5 \%$ (Molle \& Winther, 1979).

\section{Conclusions}

Although there are possibilities for markedly improving the efficiency of use of support energy in high-temperature dehydration, this method of conservation would still involve higher monetary and energy costs than either hay or silage making. Consequently, it is difficult to foresee any increase in the adoption of hightemperature dehydration. Dried forage that is produced can, however, be used very effectively in the diet of high-yielding dairy cows because of low protein degradability in the rumen and high intake potential.

There are promising possibilities for improving the nutritive value of hay by physical or chemical treatment, but more research is required to determine optimal levels of chemical addition in relation to DM content at harvest and storage conditions. Such technology, however, may make the distinction between haymaking and ensilage as methods of conservation less clear. Other developments, including the introduction of machinery capable of harvesting both wet crops for storage in silos and dried crops for storage as hay (such as the forage wagon) are likely to contribute to this trend. Thus in the future, the ideal method of forage conservation may comprise some field-drying (to avoid the problem of effluent from silos, and to restrict fermentation) but with harvest at between 50 and $70 \%$ DM content (to avoid prolonged field-drying) with addition of a preservative which may also effect an increase in the nutritive value of the product so that is is higher than that of the original crop at cutting.

\section{REFERENCES}

Barber, W. P. \& Altman, J. F. B. (1976). Proc. Ist Hay Res. Disc. Group, Nat. Inst. Agric. Enging. Dec. 1976.

Beever, D. E. \& Thomson, D. J. (1977). In Recent Advances in Animal Nutrition pp. 66-82. [W. Haresign and D. Lewis, editors]. London: Butterworths.

Castle, M. E. \& Watson, J. N. (1975). J. Br. Grassld Soc. 30, 217.

Christensen, B. H. (1967). Occ. Symp. 3, Br. Grassld Soc. p. 86.

Culpin, C. (1962). F. Br. Grassld Soc. 17, 150.

Demarquilly, C. \& Jarrige, R. (1970). Proc. XI Int. Grassld Congr. Surfer's Paradise, Australia, p. 733 .

Electricity Council (1975). Hay Drying. Farm Electric Handbook No. 22.

Forbes, T. J., Dibb, C., Green, J. O., Hopkins, A. \& Peel, S. (1980). Rep. GRI/ADAS foint Perm. Past. Grp (In the Press). 
Goering, H. K. \& Waldo, D. R. (1979). Proc. 2nd int. Gn Crop Drying Congr. Saskatoon, Canada, p. 277.

Haines, W. J. E. (1979). Grass $23,13$.

Heath, S. R., Wilkins, R. J., Windram, A. \& Foxell, P. R. (1979). Proc. 2nd int. Gn Crop Drying Congr. Saskatoon, Canada, p. 98.

Hill, J. D. (1976). Ag. Met. I7, 195.

Holden, M. R. \& Sneath, R. W. (1980). Occ. Symp. I1, Br. Grassld Soc. (In the Press).

Jackson, M. G. (1977). Anim. Fd Sci. Technol. 2, 105.

Jones, G. E. (1979). Grassland Farmers in England and Wales, Rep. Univ. Reading Agric. Exten. \& Rural Devt. Centre.

Jones, L. \& Prickett, J. (1979). In Water Control and Grassland Productivity Proc. Winter Mtg Br. Grassld Soc. p. Ir.I.

Jouin, C. (1979). Proc. 2nd int. Gn Crop Drying Congr. Saskatoon, Canada, p. 228.

Klinner, W. E. (1976). Rep. 2I Nat. Inst. Agric. Engnrng, Silsoe, UK.

Klinner, W. E. \& Shepperson, G. (1975). J. Br. Grassld Soc. 30, 259.

Knapp, W. R., Holt, D. A. \& Lechtenberg, V. L. (1974). Agron. f. 66, 823.

Knight, R. \&c Barber, W. P. (1980). Occ. Symp. I1, Br. Grassld Soc. (In the Press.)

Kuntzel, H., Lesham, Y. \& Pahlow, G. (1980). Occ. Symp. 11 , Br. Grassld Soc. (In the Press.)

Kunz, W. (1979). Proc. 2nd int. Gn Crop Drying Congr. Saskatoon, Canada, p. 252.

Lacey, J., Lord, K. A. \& Cayley, G. R. (I980). Occ. Symp. I1, Br. Grassld Soc. (In the Press.)

McCarrick, R. B. (1966). Proc. $X$ int. Grassld Congr. Helsinki, p. 575.

Milk Marketing Board (1977). An Analysis of LCP Costed Farms, 1976/77. Reading: Milk Marketing Board.

Ministry of Agriculture Fisheries and Food (1975). A. Rep. ADAS Science Arm, 1973, p. 129. London: H.M. Stationery Office.

Ministry of Agriculture Fisheries and Food (1976). Grass in the UK, Rep. Econ. Div. III. London: H.M. Stationery Office.

Ministry of Agriculture Fisheries and Food (1977). A. Rep. ADAS Reg. Agric. Sci. Serv. 1976, p. 125. London: H.M. Stationery Office.

Ministry of Agriculture Fisheries and Food (1978). Silage Making, ADAS Booklet 9. London: H.M. Stationery Office.

Ministry of Agriculture Fisheries and Food (1979). A. Rep. ADAS Reg. Agric. Sci. Serv. 1978, p. go. London: H.M. Stationery Office.

Mogensen, S. N. \& Israelsen, M. (1979). Proc. 2nd int. Gn Crop Drying Congr. Saskatoon, Canada, p. 237.

Molle, K. G. \& Winther, P. (1979). Proc. 2 nd Hay Res. Disc. Group, January 1979.

Mwakatundu, A. G. K. \& Owen, E. (1974). E. Afr Agric. Forest. 7. 40, I.

National Economic Development Office (1977). Animal Feedingstuffs London: Agric EDC, NEDO.

Osbourn, D. F., Beever, D. E. \& Thomson, D. J. (1976). Proc. Nutr. Soc. 35, 191.

Sheldrick, R. D. \& Wilkinson, J. M. (I980). ADAS Q. Rev. (In the Press.)

Shepperson, G. (1960). Proc. 8th int. Grassld Congr. Reading, p. 70r.

Spatz, G., Elmern, J. van \& Lawrynowicz, R. (1970). Bayer. Landzo. fb. 47, 446.

Spedding, C. R. W. \& Diekmahns, E. C. (1972). Comm. Agric. Bur. Bull 49, p. 387.

Staniforth, A. R. (1 979). Cereal Straw Oxford: Oxford University Press.

Strickland, M. J. (1974). F. Br. Assn. Gn Crop Driers 8, 3 .

Strickland, M. J. (1 979). Proc. 2nd Hay Res. Disc. Group, January 1979.

Tas, M. (1979). Proc. 2nd Hay Res. Disc. Group, January 1979.

Tayler, J. C. \& Aston, K. (1976a). Anim. Prod. 23, 197.

Tayler, J. C. \& Aston, K. (1976b). Anim. Prod. 23, 211.

Tayler, J. C. \& Lonsdale, C. R. (1970). Proc. Mtg Eur. Assoc. Anim. Prod. Godollo, Bulgaria.

Taylor, W. J. (1979). Proc. 2nd int. Gn Crop Drying Congr. Saskatoon, Canada, p. 216.

Tetlow, R. M. (I980). A. Rep. Grassld Res. Inst. 1979 (In the Press).

Tetlow, R. M., Wilkinson, J. M., Cammell, S. B. \& Spooner, M. C. (1979). A. Rep. Grassld Res. Inst. 1978, p. 46.

Thomas, C. (1980). Proc. ARC Seminar, Harrogate, November 1979 (In the Press).

Thomas, C., Gibbs, B. G. \& Tetlow, R. M. (1980). A. Rep. Grassld Res. Inst. (In the Press). 
Van Den Broek, A. (1979). Proc. 2nd int. Gn Crop Drying Congr. Saskatoon, Canada, p. 257.

Walsh, A. (1979). In Grass in Dairy Cow Nutrition, p. 2. Imperial Chemical Industries Ltd. White, D. J. (1980). Occ. Symp. 11 , Br. Grassld Soc. (In the Press).

Wilkinson, J. M. (1980a). Ann. Appl. Biol. (In the Press).

Wilkinson, J. M. (1980b). Occ Symp. I 1, Br. Grassld Soc. (In the Press).

Wilkinson, J. M. (1980c). Proc. Symp. Univ. Reading, September 1980 (In the Press).

Zimmer, E. (1977). Proc. int. Mtg Anim. Prod. Temp. Grassld Dublin, Eire, p. 21. 